\title{
Innovation Orientation Outcomes: The Good and the Bad
}

\author{
Penny M. Simpson \\ The University of Texas - Pan American \\ Judy A. Siguaw \\ Cornell-Nanyang Institute of Hospitality Management \\ Cathy A. Enz \\ Cornell University
}

\begin{abstract}
Most prior innovation research has focused on factors that affect innovations, primarily rate, speed and benefits. More recent research has examined innovation as a system-based, firm-wide orientation toward innovation. Along with this broader perspective comes a need for understanding outcomes of the orientation, both positive and negative. This paper uses grounded theory methodology to develop such a framework of outcomes of an innovation orientation based on interviews with executive experts. The study results provide guidance to practitioners considering a firm-wide innovation orientation and avenues for further study for academics.
\end{abstract}

An innovation-oriented knowledge structure is a set of organization-wide shared beliefs and understandings that guide and direct "all organizational strategies and actions, including those embedded in the formal and informal systems, behaviors, competencies, and processes of the firm" (Siguaw et al., 2006) and, in large part, drives a firm's ability to innovate continuously, according to recent research (e.g., Calantone et al., 2002; Siguaw et al., 2006). In this conceptualization, the innovation-oriented firm focuses on developing key organizational competencies in resource allocation, technology, employees, operations and markets.

This system-wide view of innovation is in contrast to the vast innovation literature which focuses primarily on product and process innovations and factors that affect the innovations produced (e.g., Caldwell and O'Reilly, 2003; Morrison et al., 2000). Theoretically, in this expansive view, the knowledge capital surging throughout the firm is continuously growing, and morphing to identify the next position needed to keep an organization abreast of competitors and markets, making innovations throughout the firm pervasive and continual. Such capability for organization-wide innovation should lead to broad strategic consequences beyond simple innovation counts, which are just beginning to receive due attention fueled by knowledge-based theory (e.g., Martin and Salomon, 2003). 
This paper explores the likely consequences, both positive and negative, that may result from the deployment of an innovation orientation knowledge structure. While numerous studies have examined innovation-related outcomes, such as rate, number and type of innovation, few studies have investigated the positive and detrimental effects resulting from an innovation orientation (exceptions include Lukas and Menon, 2004; Olson et al., 2005; Sharma and Lacey, 2004), leaving a considerable gap in the existing innovation literature. This study should diminish this void by providing a framework of potential outcomes that result from an innovation orientation.

The framework and researchable propositions offered herein will substantially add to the innovation literature by utilizing the firm-wide perspective of innovation orientation, identifying both positive and negative outcomes that may arise from an innovation orientation, and proposing a theoretically grounded agenda for examining innovation orientation outcomes. Study results are especially important because of the potentially high cost of an innovation orientation and because little academic research has focused on the pitfalls resulting from innovations or an innovation-oriented strategy. For practitioners, this work provides a comprehensive and realistic perspective for firms considering adopting an innovation orientation.

\section{Innovation Outcome Research Obstacles}

Progress in identifying outcomes of an innovation orientation has likely been hindered by three key obstacles: (1) a predominant reliance on a few, positive outcome measures, (2) a concentration on inputs, and (3) a bias toward positive results. These roadblocks and plans for overcoming them in this paper are discussed next.

\section{Reliance on Few, Positive Outcomes Measures}

The innovation literature to date has largely relied on a handful of specific, readily calculated outcomes of innovation, with few studies examining the link between a more comprehensive innovation orientation and its organizational effects (Totterdell et al., 2002). Examples of specific innovation outcomes investigated previously include number of innovations adopted (Han and Srivastava, 1998), performance (e.g., Hult et al., 2004), stock market value (e.g., Sharma and Lacey, 2004), new product introduction, R\&D expenditures, and order of market entry (e.g., Manu and Sriram, 1996). Largely missing from these outcomes studies are factors such as improved employee morale (a notable exception is Zhou et al., 2005), enhanced customer loyalty, and any negative effects, such as employee stress and reduced product qualify (Lukas and Menon, 2004 is an exception), which may arise from a firm's innovation orientation.

\section{Concentration on Inputs}

With a few exceptions (e.g., Hult et al., 2004; Lukas and Menon, 2004; Olson et al., 2005), prior innovation research focused on antecedent factors that affect new product 
innovations, type or rate of innovations, and normative implementation activities (for example, Van de Ven et al., 1999). While these contributions are important, a broader understanding of innovation effects is crucial as well, since the micro-level focus generally ignores effects of an innovation orientation on a firm's sustained financial performance.

\section{Positive Effect Bias}

Considering the lack of negative outcomes discussed in the literature, effects of an innovation orientation are generally assumed to be positive and desirable; yet, a highly innovation-oriented organizational philosophy will have pit- falls. Indeed, Olson et al. (2005) find that, for three of the four Miles and Snow (1978) strategic archetypes, innovation orientation has a negative or neutral effect on business performance. These results suggest that an understanding of the unintended outcomes of an innovation orientation, especially the harmful ones, is essential to firms considering an innovation orientation.

This study overcomes these obstacles to innovation outcomes research by using a sample of executive-level respondents combined with previous knowledge to identify key organizational outcomes of an innovation orientation. Results should advance the innovation orientation outcomes research stream and assist managers in measuring the value and risk of an innovation orientation.

\section{Methodology and Analysis}

Grounded theory is appropriate when little prior research or theory exists to guide researchers in hypotheses development (Carson et al., 2001) and "is more likely to generate novel and accurate insights into the phenomenon under study than reliance on either past research or office-bound thought experiments," (Brown and Eisenhardt, 1997, p. 2). This methodology requires that researchers analyze responses from informed constituents to identify inherent patterns. These patterns, combined with related research findings, establish the bases for theory grounded in empirical findings. Because of limited prior innovation orientation outcomes theory and research, especially with regard to negative outcomes, a grounded theory methodology was used here.

Respondents in the best position to observe and report potential effects of a firm-wide innovation orientation are high-level executives and entrepreneurs instrumental in setting and monitoring firm strategy. A sample of 200 of these types of decision-makers from various industries who had graduated from a university ten or more years previously were sent an email inviting study participation. The businesses represented by the respondents were diverse (see Table 1) but were primarily business-to-business services and goods industries (61\%) located throughout the United States. A total of 54 in-depth interviews (27\%) were completed and the sample demographic characteristics are shown in Table 1. While this sample size may restrict the generalizability of results, Mariampolski (2001, p. 78) notes that "most studies are effectively conducted with ... 15-30 individual in-depth interviews." 
As part of a larger study, all participating executives were sent a copy of ten broad, open-ended questions related to innovation orientation prior to interviews. The key questions relevant to this study include: What is innovation orientation? What are the positive consequences of these innovations? and What are the negative consequences? All interviews were conducted by the authors who asked the open-ended questions but then probed to elicit greater detail or clarification as needed. Without any prompting about types of outcomes attributable to an innovation orientation, respondents used their experiences to identify both positive and negative outcomes that may arise from an orientation toward innovation. The telephone interviews ranged from 25 to $90 \mathrm{~min}$ and were tape-recorded and transcribed for analysis.

\begin{tabular}{|c|c|c|}
\hline Characteristic & Classification & Percentage \\
\hline \multirow[t]{6}{*}{ Title } & Chairman of the Board & $1.9 \%$ \\
\hline & $\mathrm{CFO}$ & $1.9 \%$ \\
\hline & President/owner & $20.8 \%$ \\
\hline & Vice president & $35.8 \%$ \\
\hline & Director & $18.9 \%$ \\
\hline & Senior Manager & $20.8 \%$ \\
\hline \multirow[t]{2}{*}{ Positions } & Marketing & $32.1 \%$ \\
\hline & Non-marketing & $67.9 \%$ \\
\hline \multirow[t]{15}{*}{ Industry } & Hospitality and tourism & $18.5 \%$ \\
\hline & Consulting & $16.7 \%$ \\
\hline & Financial services & $9.3 \%$ \\
\hline & Food services & $9.3 \%$ \\
\hline & Software/info. systems & $7.4 \%$ \\
\hline & Support services & $7.4 \%$ \\
\hline & Entertainment & $5.6 \%$ \\
\hline & Publishing & $5.6 \%$ \\
\hline & Advertising & $5.6 \%$ \\
\hline & Real estate & $3.7 \%$ \\
\hline & Energy/utilities & $3.7 \%$ \\
\hline & Commercial interior design & $1.9 \%$ \\
\hline & Manufacturing & $1.9 \%$ \\
\hline & Furniture/equip. distribution & $1.9 \%$ \\
\hline & Market research services & $1.9 \%$ \\
\hline \multirow[t]{2}{*}{ Ages } & Range & 31 to 75 years \\
\hline & Mean & 44.8 years \\
\hline \multirow[t]{2}{*}{ Gender } & Male & $77.0 \%$ \\
\hline & Female & $23.0 \%$ \\
\hline \multirow[t]{5}{*}{ Geographic location } & Northeast & $35.2 \%$ \\
\hline & Mid-Atlantic & $11.1 \%$ \\
\hline & South & $16.7 \%$ \\
\hline & Midwest & $14.8 \%$ \\
\hline & West & $22.2 \%$ \\
\hline
\end{tabular}

Table 1 Demographic characteristics of respondents

Following content analysis protocol (Carson et al., 2001), one author developed a listing of consequences of an innovation orientation surfaced by interviewees for coding purposes. The other authors then attempted to code each respondent thought about innovation orientation outcomes into the listed categories. Discussions among authors led to several 
revisions of the coding categories until all authors were satisfied that the crux of each respondent answer would fit into a category shown on the coding form (see Table 2). Each author then reread each interview and coded each issue expressed as an innovation outcome into the appropriate category. The authors then compared and discussed differences in coding to arrive at a $100 \%$ agreement. Finally, the authors grouped logically similar categories together into the key positive and negative effects of innovation orientation shown in Table 2.

The resulting data patterns indicated the positive consequence classifications to be: innovation-related outcomes (30.3\%), market advantages (28.7\%), employee advantages (14.2\%), and operational excellence (7.1\%). Negative consequence classifications are: increased costs (41.1\% of all negative responses), change for change sake (24.6\%), market risk (21.6\%), and employee attitudes (12.8\%) as shown in Fig. 1. Each outcome type and supporting commentary from interviews and derived propositions for empirical testing are discussed next.

\section{Positive Outcomes of Innovation Orientation}

\section{Innovation}

Most respondents indicate that an innovation orientation should impact the number, rate, and type of innovations a firm produces. For example, quantity of innovations, characterized as 'more innovations or ideas,' and shorter cycle times were frequently mentioned as consequences. To date, innovation research has partially substantiated the respondents' observations. Specifically, innovation-oriented firms tend to adopt more radical and incremental innovations (Tushman and O'Reilly, 1996), and at a faster rate (Kessler and Chakrabarti, 1996; Vazquez et al., 2001).

Many respondents caution that the number, rate and type of innovations generated by innovation-oriented firms will likely increase financial performance only up to an ideal point beyond which the positive effects of innovation diminish. For example, those who identify 'faster to market' as a positive outcome, of innovation orientation also observe that desired 'speed depends on the complexity of the innovation.' Providing support are empirical findings that shorter development times, on average, are unrelated to overall success of new product innovations (Griffin, 2002) and that innovation cycle time is contingent upon innovation type (Kessler and Chakrabarti, 1999) and meaningfulness (Im and Workman, 2004). The ideal point for the number of innovations and for cycle time is likely shaped by the conflict and pressure for qualify within a firm, and the firm's ability to effectively manufacture and market the innovations quickly. An ideal point in the innovation literature has received little study except by Barnett and Freeman (2001) who find that simultaneous introduction of multiple innovative products actually increased organizational failure.

Other respondents feel that innovative firms produce better quality products, not necessarily more products: "It [innovation orientation] doesn't really affect the number...instead they focus on the style to be brought forward... what you are actually looking for is a very high quality idea or one that can be used, not necessarily sixty good ones." 


\begin{tabular}{|c|c|c|c|}
\hline $\begin{array}{l}\text { Positive } \\
\text { outcomes }\end{array}$ & $\begin{array}{l}\text { Positive } \\
\text { responses } \\
(n=184)\end{array}$ & $\begin{array}{l}\text { Negative } \\
\text { outcomes }\end{array}$ & $\begin{array}{l}\text { Negative } \\
\text { responses } \\
(n=102)\end{array}$ \\
\hline $\begin{array}{l}\text { Innovation-related } \\
\text { Outcomes }\end{array}$ & $30.3 \%$ & Increased Costs & $41.1 \%$ \\
\hline More innovations/ideas & $10.9 \%$ & Costs & $19.6 \%$ \\
\hline Shorter cycle times & $8.2 \%$ & Takes time to innovate & $8.8 \%$ \\
\hline $\begin{array}{l}\text { Increased innovative } \\
\text { productivity (quality } \\
\text { and quantity) }\end{array}$ & $2.7 \%$ & Wasted effort & $6.9 \%$ \\
\hline $\begin{array}{l}\text { Timing of innovation } \\
\text { modifications }\end{array}$ & $2.2 \%$ & More mistakes & $2.9 \%$ \\
\hline Product quality & $1.6 \%$ & $\begin{array}{l}\text { Sacrifice short-term } \\
\text { gains }\end{array}$ & $2.9 \%$ \\
\hline $\begin{array}{l}\text { Focus on strengths } \\
\text { (more is not } \\
\text { necessarily better) }\end{array}$ & $1.6 \%$ & $\begin{array}{l}\text { Change for Change } \\
\text { Sake }\end{array}$ & $24.6 \%$ \\
\hline $\begin{array}{l}\text { Simultaneous } \\
\text { innovation } \\
\text { throughout the } \\
\text { organization }\end{array}$ & $1.6 \%$ & $\begin{array}{l}\text { Focus on innovation } \\
\text { outside of core } \\
\text { competency }\end{array}$ & $13.7 \%$ \\
\hline $\begin{array}{l}\text { Ideal number of } \\
\text { innovations }\end{array}$ & $0.5 \%$ & $\begin{array}{l}\text { Constituents don't buy } \\
\text { into innovation }\end{array}$ & $5.9 \%$ \\
\hline $\begin{array}{l}\text { Ideal cycle time of } \\
\text { innovations }\end{array}$ & $0.5 \%$ & $\begin{array}{l}\text { Caught up in } \\
\text { innovating, forgetting } \\
\text { key details }\end{array}$ & $4.9 \%$ \\
\hline $\begin{array}{l}\text { Continuous incremental } \\
\text { innovation }\end{array}$ & $0.5 \%$ & & \\
\hline Market Advantages & $28.7 \%$ & Market Risk & $21.6 \%$ \\
\hline Competitive advantage & $13.0 \%$ & Innovation failures & $20.6 \%$ \\
\hline Customer satisfaction & $7.6 \%$ & Reputation/image & $1.0 \%$ \\
\hline $\begin{array}{l}\text { Company image/ } \\
\text { reputation }\end{array}$ & $4.3 \%$ & & \\
\hline Customer loyalty & $1.6 \%$ & & \\
\hline $\begin{array}{l}\text { New approaches to } \\
\text { markets or } \\
\text { distribution }\end{array}$ & $1.1 \%$ & & \\
\hline $\begin{array}{l}\text { Ability to continuously } \\
\text { reinvent }\end{array}$ & $1.1 \%$ & & \\
\hline Employee Advantages & $14.2 \%$ & Employee Attitudes & $12.8 \%$ \\
\hline $\begin{array}{l}\text { Employec satisfaction/ } \\
\text { retention }\end{array}$ & $12.0 \%$ & $\begin{array}{l}\text { Some people can't } \\
\text { handle change/hurt } \\
\text { employee feelings }\end{array}$ & $6.9 \%$ \\
\hline Employee recruitment & $2.2 \%$ & $\begin{array}{l}\text { Some employees need } \\
\text { structure }\end{array}$ & $3.9 \%$ \\
\hline Operational excellence & $7.1 \%$ & Job displacement & $1.0 \%$ \\
\hline Productivity, efficiency & $7.1 \%$ & Hard work & $1.0 \%$ \\
\hline
\end{tabular}

Table 2 Categories of outcomes responses 


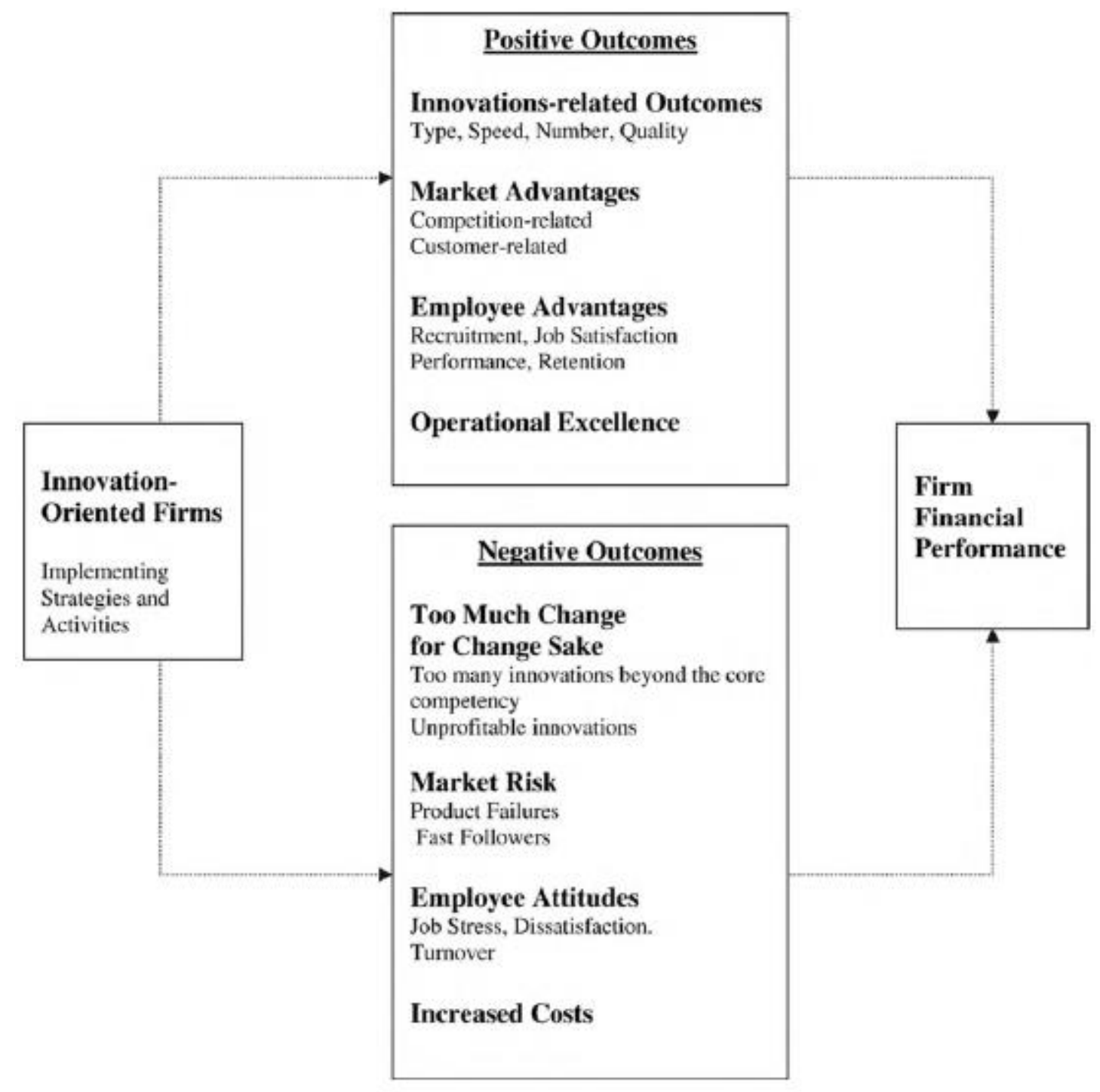

Broken lines indicate relationships that likely exist, but ure not examined in this study.

Fig. 1. Model of innovation orientation firm outcomes.

Similarly, the president of a communication company comments: "You have to limit yourself to the things where you can be a real strong contributor and push the frontier way, way out and that may say that you would be better off working on fewer rather than more innovations with the idea that you would be able to do a far better job."

With a few exceptions, the literature largely overlooks innovation quality as a viable outcome of an innovation orientation, an outcome explicitly noted by study respondents; hence, quality is included in the model of innovation orientation outcomes shown in Fig. 1. The Lukas and Menon (2004) conclusion that "too little as well as too much NPD [new product development] speed has a negative effect on new product qualify" (p. 1262) and the Cho and Pucik (200S) finding of the combined importance of innovativeness and quality in affecting firm 
performance and growth provides some empirical support to the respondents' quality outcome contention. The preceding discussion suggests the following for empirical testing:

PI. Highly innovation-oriented firms will lead their industry in a) producing radical and incremental innovations up to an ideal point, b) bringing innovations to market faster up to an ideal point, and c) developing higher quality innovations of all types.

\section{Market Advantages: Competitors and Consumers}

Two market-based advantages of an innovation orientation are described by the executives in this study: competitive advantages and customer benefits. Innovation-oriented firms focus on the creation and implementation of novel ideas, products and services that will succeed in the marketplace. Thus, an ability to anticipate consumer needs and respond better than competitors should generate significant benefits to innovation- oriented firms.

\section{Customers}

Respondents believe that an innovation-oriented firm will derive consumer benefits including enhanced customer satisfaction, loyalty, and image. The interviewees' customerrelated comments focused on long-term customer relationships, customer needs, customer value, ability to charge higher prices, larger market appeal, and corporate image. Specific examples are: "To the extent that they are successful in the projects, their reputation would be enhanced," "Ability to adapt to the market faster," and "Have a unique value proposition for the customer." One marketing manager of a publishing firm notes that innovation orientation "creates brand awareness in the marketplace. Consumers want to be a part of that brand and they want to take hold of it however they can." Finally, a consulting firm owner states:

There is a customer philosophy which is communicated to the customer which generates a belief that the service or product provider is, in fact, acting in the customers' interest on a long-term basis and trying to develop that relationship...the organization is recognized as a leader in the industry in terms of satisfying its customers... It provides the ability to say 'how do we meet the long-term relationship needs of our clients?' not 'how do we push the product to them?

Though no known studies have empirically examined innovation orientation effects on consumers, Schlegelmilch et al. (2003) make a compelling argument that a strategic innovation will yield 'proactive value creation' and Totterdell et al. (2002) find a relationship between novelty and greater perceived benefits to customers. This research implies that innovative firms proactively anticipate consumer needs and respond accordingly, creating greater value for consumers. This theoretical evidence coupled with respondents' answers suggests:

P2. Highly innovation-oriented firms will lead their industry in customer satisfaction and loyalty. 


\section{Competitors}

Study respondents indicate that competitive advantage likely arises from an innovation orientation strategy. Competitor- related outcome terms mentioned by the interviewees consist of 'market leader', 'greater growth', 'future-oriented', 'competition related/competitive advantage', 'creation of barriers to entry', and 'ability to adapt quickly to changes in the marketplace'. Examples of such comments include:

- "It certainly helps define that organization or company as a leader which has additional positive implications relative to how it and its products or services are perceived both by customers as well as by its competitors as well as by any analyst."

- "It gives an organization the ability to make a quantum leap over their competition. They can have a view into the future that others don't have."

- "There is also the issue of perceptual leadership or the perception of leadership in a category."

Though innovative firms may continuously monitor their competitors, they "set out to make competition irrelevant," (Schlegelmilch et al., 2003, p. 126) by creating the market, not just running with the pack. Hurley and Hult (1998) substantiate this competitive edge of innovation oriented firms by modeling a relationship between firm innovativeness, capacity to innovate and competitive advantage, arguing that "Firms with greater capacity to innovate will be more successful in responding to their environments and developing new capabilities that lead to competitive advantage and superior performance" (p. 45).

Although the empirical link between an innovation orientation and market leadership on various measures has yet to be firmly established, logic suggests the link for several reasons. Innovation-oriented firms should, theoretically, provide a clear competitive advantage because the products are unique in the marketplace, the products are designed to meet market needs, and more company resources are devoted explicitly toward R\&D and innovation. Some empirical research provides support (see Tidd, 2001 for a review). For example, Tidd notes that the "PIMS [Profit Impact of Market Strategy] database suggests that market share has a much stronger impact on profitability in innovative sectors..." (p. 172) and Lyon and Ferrier (2002) report a link between the number of new products and increased market share. With the caveat that firms may choose not to be the biggest, best, or fastest in the industry, the respondents' observations and existing research suggest the following proposition:

P3. Highly innovation-oriented firms will lead their industry in company-specified competitionrelated measures, such as market share.

\section{Employee Advantages}

An innovation-oriented environment will likely lead to greater enjoyment, selffulfillment, and job satisfaction by employees who remain in this challenging, demanding, but intrinsically satisfying work situation. As one respondent notes, "people want to be able to use 
their creative thought and to stretch their minds." Other respondents remark, "It becomes a more enjoyable environment in a sense that more people have a share of being involved and have a more proprietary interest," and "It enriches the whole work experience."

Study respondents suggest specifically that employee-related benefits of an innovationoriented firm will include personal satisfaction, a proprietary interest in ideas, lower turnover rates, higher employee morale and enhanced productivity. In addition, respondents believe that employee satisfaction, recruitment of better employees, and increased salaries or bonuses from successful innovations will result. As examples, one respondent says, "Perhaps the most often overlooked benefit is that the members of the organization feel that there is a horizon of opportunity beyond their current activity and that generates a feeling of not only organizational affiliation but also a long-term commitment to the company," while a director of special development believes, "You'll have happier people; the happier they are, the more good ideas you'll have bubble up through the system. The more good ideas bubble up, the more successfid you're going to be."

Workforce effects of an innovation-oriented firm have long been assumed (e.g., Cozijnsen, 1993), but have limited empirical substantiation in the literature. For example, Gallivan (2003) finds a relationship between innovator creative style and job attitudes, such as satisfaction and elements of job performance, in a mandated innovation acceptance situation. Congruent with person-environment fit theory, Totterdell and colleagues $(2002$, p. 357$)$ report that innovation provides "greater benefits to employee relations" in certain situations, and Zhou et al. (2005) find that an innovation orientation improves employee job satisfaction and organizational commitment. These empirical findings from prior research coupled with respondents' comments suggest:

P4. Highly innovation-oriented firms will lead their industry in employee a) recruitment, b) satisfaction, c) performance, and d) retention.

\section{Operational Excellence}

An innovation orientation provides a firm with the capability of developing and implementing innovations. Innovations that occur in methods, techniques, information flows, and equipment are generally termed process or administrative innovations (Afuah, 2003). An organization that has developed an orientation to innovate will not only increase the number of these types of innovations, as previously argued, but will experience enhanced operational efficiency. Our respondents suggest as much with such commentaries as "better, faster or more efficient than the competition," "more efficient and more effective," "increases productivity" and "these new operational systems will save us time and money and will help us to be more efficient and effective."

Few studies provide evidence of operational efficiencies or organizational performance arising from intraorganizational process innovations (Damanpour and Shanthi, 2001). However, 
Subramanian and Nilakanta (1996) report significant effects of innovativeness on measures of organizational efficiency and effectiveness and Pae et al. (2002) found a direct relationship between level of organization process innovation diffusion and organizational performance in a buying center context. A study of the banking industry by Damanpour and Shanthi (2001) suggests enhanced firm performance from investing in product and intraorganizational process innovations synchronously, rather than in product innovations alone. Recent empirical evidence from the securities industry finds that firms failing to respond to technological innovation experience large decreases in both efficiency and productivity (Zhang et al., 2006). Respondent comments and the limited theoretical bases provide support for the proposition:

P5. Highly innovation-oriented firms will lead their industry in operational efficiency.

\section{Negative Outcomes}

Both the academic literature and the popular press offer scant attention to the downside of a pervasive organizational strategy that emphasizes innovation, although a few articles suggest that some of the most innovative firms end up failures (e.g., Han et al., 2001; Hawn, 2004). This lack of focus on negative consequences is unfortunate since a more balanced view of the consequences of innovation orientation would facilitate management choices. Moreover, negative effects of an innovation orientation may actually outweigh the positive ones, but the lack of research offers no evidence either way. Our respondents warn that several noteworthy pitfalls may confront organizations that foster an innovation-orientation: too many changes for change sake, market risk, employee resistance, and increased costs.

\section{Too Many Changes for Change Sake}

Innovation-oriented firms may become too enamored with the idea of innovations, creating more innovations for the sake of innovation. Such firms lose sight of the costs of those innovations, get lost in R\&D without realizing benefits from the research, fail to adequately consider consumer needs in the innovation process, commercialize innovations too quickly, and forego efficiencies. As one respondent observes, innovation- oriented firms must "be on the leading edge, not the bleeding edge." Another echoes the sentiment with "you don't have to change just for change sake."

A number of respondents caution that highly innovation- oriented firms may stray from the firm's core competencies. The key, according to one executive, is not "a lot of good ideas" but rather "to its execution." Other related comments are:

- "You could be too focused on being innovative and take your eye off the core competencies of what you're supposed to be doing,"

- "You can get too focused on innovation and lose track of solid business practices,"

- "I think the most common potential negative is that the innovation becomes an end unto itself rather than an integrated part of the business practice and therefore a novelty becomes a goal rather than the satisfaction of the customer." 
A senior manager of a large consulting firm references an especially innovative client to make her point: "they became so good at creating great things for clients without maintaining a focus on cost-effective distribution and cost-effective production."

The literature supports the respondents' contentions. Laursen and Salter (2006) find that extensive external knowledge search and depth negatively affect innovation performance beyond a certain "tipping" point. Cooper (1994) reports that firms that introduce innovations outside of their usual competency experience lower market share and profitability, and both Manu and Sriram (1996) and Olson et al. (2005) find negative effects of innovativeness on firm performance, where effects differ respectively by firm innovator or strategic type. Accordingly, we propose:

P6a. Highly innovation-oriented firms will lead their industry in creating innovations outside their core competencies.

P6b. Highly innovation-oriented firms will lead their industry in unprofitable innovations.

\section{Market Risk}

The development, adoption and implementation of innovations involve considerable market risk as evidenced by a new product failure rate in 2005 of 80\% (Pombriant, 2006). A firm philosophy that emphasizes and rewards continuous innovation may exacerbate market failures in the absence of appropriate innovation limiting measures. This idea is noted by study respondents. One vice president of a construction/realty company notes that companies often provide more "bells and whistles" than most consumers need or want and that "sometimes too much innovation confuses the marketplace." This idea is supported by research finding that consumers seem to want meaningful innovations, not just novel ones (Cooper 1994; Im and Workman 2004).

Another respondent suggests that one innovation orientation outcome is likely "spending too much money on it [innovations] and not realizing the benefits of it..not being able to capitalize on it." Thus, the development and execution of innovations may increase the innovation failure rate of a firm while enabling fast followers who copy the successful technology without the related expenses of innovation trial and error, harming the marketplace position of the firm. Either the fast-follower problem or the 'too novel' problem or both may explain why Gatignon et al. (2002) find that incrementally improved products have greater commercial success than radically new products. Considering the high failure rate of new products and the possibility of imitation:

P7. Highly innovation-oriented firms will lead their industry in innovation failure rates and fastfollower imitation.

\section{Employee Stress, Dissatisfaction and Turnover}

The work environment of an innovation-oriented firm must encourage and facilitate 
continual creativity and change. Our respondents warned that while many employees find this environment challenging and rewarding, others are far more comfortable in a structured, stable and unchanging environment. As one respondent stated, innovation-oriented firms are "fundamentally promoting chaos... [which] may actually scare some people away," while another respondent felt they "reduce a comfort level in processes." A vice president of an energy company remarks: "It induces a rapidly changing work environment. There are just some people that can't take it. We do lose some really skilled technical talent because they can't manage in this environment."

Employees unable to adapt to an innovation-oriented environment may experience high levels of stress and dissatisfaction. The few studies that focus on negative employee effects of an innovation environment provide some support. Lukas et al. (2002) find that speed of product invention, defined as "bringing new ideas into being," (p. 352) increases organizational stress while speed of product innovation decreases organizational stress.

Another respondent has a different employee-outcome concern; he suggests that workers "can get lazy under a very loose structure" required in innovative environments. Additionally, innovations throughout the firm, especially in processes or administration, may reduce the need for labor, creating another problem that workers may face in an innovationoriented firm, according to one respondent.

Given the limited empirical research to date that may substantiate or refute respondents' conjectures about employee responses to an innovation orientation, the following is offered:

P8. Highly innovation-oriented firms will lead their industry in employee a) job stress, b) dissatisfaction and c) turnover.

\section{Increased Costs}

Most all activities associated with innovation, such as R\&D expenditures and product and idea failure, are likely to result in increased costs, as noted by study participants. One respondent articulates the concern: "A lot of times people spend a lot of money to be innovative and it doesn't work or there is not a demand," while another states "It's expensive... it's capital intensive to create these companies that are large innovators." In another case, an advertising manager, citing the slow-to-adoption wireless technology, was concerned with costs associated with product innovation where the pace of innovation exceeds demand-when an innovation is "before its time."

Firms more dedicated to innovating will devote more resources to the cause. This relationship is generally seen in the large number of research articles using R\&D expenditures as a proxy for innovation, suggesting that increased expenditure means more innovations. The costs associated with being a first-mover offers some indirect support for the substantial expenses incurred by innovation-oriented firms (Van de Ven et al., 1999). Despite the 
importance of spending on resources to develop innovations, past innovation research rarely addresses the costs of innovation. Miller et al. (1988) conclude that product innovation is generally very costly with the costs rarely recovered and Kessler and Chakrabarti (1996) posit that faster innovations will work to reduce long-term innovation costs. Finally, a recent study finds that more businesses are creating fewer 'true' innovative products, partly because of their failure to commit adequate resources (Cooper, 2005). Respondents' observations and limited empirical findings warrant the following:

P9. Highly innovation-oriented firms will lead their industry in investment costs.

\section{Conclusions}

Firm managers may continue with or even escalate commitments to unprofitable new product developments, despite evidence for project termination. This escalation may occur because of a continued reliance on initial positive benefits of the project, even in the face of contrary information (Biyalogorsky et al., 2006). Knowing both the pros and cons of an innovation project or strategy upfront may assist in overcoming this escalation tendency. The framework of positive and negative outcomes of an innovation orientation provided in this paper offers a more realistic and comprehensive understanding of the consequences of adopting this broad, organization-wide knowledge structure. Additionally, the proposed framework considerably broadens existing innovation research, which has, with very few exceptions, been narrow and limited in its focus.

Likely outcomes identified in the study include more, faster, and higher quality innovations, along with employee-, customer- and competition-related advantages, and operational excellence. The negative outcomes surfaced in this research include too many unwarranted changes, market risks, employee dissatisfaction, and increased costs. This framework is important to academics and managers as it provides academics with a jumping-off point for future research and it should encourage practitioners to take a holistic view of consequences of the often cost-intensive innovation orientation.

\section{Managerial Implications}

Implications for practitioners are apparent from this study. This research indicates that embracing an innovation orientation may not be the panacea that prior studies have suggested, warranting some caution. Firms should avoid producing innovations that stray beyond a firm's core competencies, recruiting employees that resist change or who cannot manage the stress of a dynamic environment, and developing measures that fail to financially account for both the positive and adverse costs of innovation. Additionally, the set of likely outcomes specified here should be used for benchmarking the success of innovations.

\section{Theoretical and Future Research Implications}

Importantly, the framework provided in this paper establishes theoretical bases for understanding and justifying an innovation orientation and sets out a future research agenda. 
First, empirical examination of the linkages between the strength of a firm's innovation orientation and the nature and degree of each of the positive and negative outcomes is needed. For example, too little is known about the relationship of quality and innovation, or about innovation and firm performance measures, such as market share, profitability or return on investments. Also, the effects of process or administration innovations on operational efficiencies are deserving of more research to further assess diffusion of innovations within an organization (Damanpour and Shanthi, 2001; Pae et al., 2002), as well as the financial implications of the successful implementation of those process innovations.

More importantly, future research should examine the relationship between innovation orientation and financial performance. An innovation orientation will likely improve the longterm performance of firms indirectly through innovation, market and employee advantages, and operational efficiency. However, these benefits may be offset by pitfalls, such as decreased short-term profitability, market risk, dissatisfied and stressed workers, and heavy investment costs. While many scholars acknowledge that firms must be innovative to grow and to create a competitive advantage (Deshpande et al., 1993), empirical support for linkages to firm performance are limited and equivocal (Tidd, 2001), and almost exclusively focused on innovativeness as a surrogate for the more robust innovation orientation conceptualization. Some researchers find positive effects of innovation on assorted measures of firm performance (e.g., Calantone et al., 2002; Hult et al., 2004; Olson et al., 2005; Sharma and Lacey, 2004); yet, a number of studies also offer opposing views (Noble et al., 2002; Manu and Sriram 1996; Olson et al., 2005). These mixed findings may be the result of the counteracting effects of short-term losses versus long-term profits; however, additional research is needed to definitively determine the cause.

Factors that may affect each outcome cited in this paper, and possible interaction effects, is another potentially rich area for study that would provide practitioners with knowledge concerning implementation of an innovation orientation. Refining the "ideal point" point at which a firm's innovation orientation efforts begin to have diminishing effects is another area of work deserving investigation, as is the study of indirect effects of an innovation orientation, such as greater channel partner acceptance. Finally, developing and implementing innovations may require considerable costs in terms of money, time, effort and other resources. The cost-benefits of the strategy and the likelihood of an escalation bias for a firmwide innovation orientation strategy also warrant future research.

\section{References}

Afuah Allan. Innovation management: Strategies, implementation, and profits. 2nd ed. Oxford UK: Oxford University Press, 2003.

Barnett William P, Freeman John. Too much of a good thing? Product proliferation and organizational failures. Org Sci 2001; 12:539-58 [September/ October], 
Biyalogorsky Eyal, Boulding William, Staelin Richard. Stuck in the past: Why managers persist with new product failures. J Mark 2006; 70(2):108-21.

Brown Shona L, Eisenhardt Kathleen M. The art of continuous change, linking complexity theory and time-paced evolution in relentlessly shifting organizations. Adm Sci Q 1997; 42:1-34 [March].

Calantone Roger J, Cavusgil Tamer S, Yushan Zhao. Learning orientation firm innovation capability and firm performance. Ind Mark Manage 2002; 31: 515-24 [September],

Caldwell David F, O'Reilly in Charles A. The determinants of team-based innovation in organizations: The role of social influence. Small Group Res 2003; 34(4):497-517.

Carson David, Audrey Gilmore, Chad Perry, Kjell Gronhaug. Qualitative marketing research. London: Sage Publications; 2001.

Cho Hee-Jae, Pucik Vladimir. Relationship between innovativeness, quality, growth, profitability, and market share. Strateg Manage J 2005; 26:555-75 [June].

Cooper Robert G. Debunking the myths of new product development. Res Technol Manage $1994 ; 37(4): 40-51$.

Cooper, Robert G. Your NPD portfolio may be harmful to your business health. Visions Magazine 2005 (April) (available online at http://www.pdma.org/ visions/apr05/npd.html).

Cozijnsen Anton. Predicting innovation success with the DIPO-instrument. In: Anton Cozijnsen, Willem Vrakking, editors. Handbook of Innovation Management Part A. Oxford UK: Blackwell Publishers; 1993. p. 95-108.

Damanpour Fariborz, Shanthi Gopalakrishnan. The dynamics of the adoption of products and process innovations in organizations. J Manag Stud 2001; 38 (1):21-65.

Deshpande Rohit, Farley John U, Webster Jr Frederick E. Corporate culture customer orientation and innovativeness in Japanese firms: A quadrad analysis. JMark 1993; 57(1):23-37.

Gallivan Michael J. The influence of software developers' creative style on their attitudes to and assimilation of a software process innovation. Inf Manage 2003; 40:443-65 [May],

Gatignon Hubert, Tushman Michael L, Smith Wendy, Anderson Philip. A structural approach to assessing innovation: Construct development of innovation locus type and characteristics. Manage Sci 2002; 48:1103-22 [September].

Griffin Abbie. Product development cycle time for business-to-business products. Ind Mark Manage 2002; 31:291-304 [July]. 
Han Jin K, Srivastava Rajendra K. Market orientation and organizational performance: Is innovation a missing link? J Mark 1998; 62:30-45 [October],

Han Jin K, Kim Namwoon, Kim Hong-Bumm. Entry barriers: A dull-one-or two-edged sword for incumbents? Unraveling the paradox from a contingency perspective. J Mark 2001; 65:1-14 [January].

Hawn Carleen. If he's so smart: Steve Jobs Apple and the limits of innovation. Fast Company 2004; 78:68-74 [January].

Hult G, Thomas M, Hurley Robert F, Knight Gary A. Innovativeness: Its antecedents and impact on business performance. Ind Mark Manage 2004; 33: 429-38 [July],

Hurley Robert F, Hult Tomas G. Innovation, market orientation and organizational learning: An integration and empirical examination. J Mark 1998; 62: 42-54 [July],

Im Subin, Workman Jr John P. Market orientation creativity and new product performance in high-technology firms. J Mark 2004; 68:114-32 [April],

Kessler Eric H, Chakrabarti Alok K. Innovation speed: A conceptual model of context antecedents and outcomes. Acad Manage Rev 1996; 21(4): 1143-91.

Kessler Eric H, Chakrabarti Alok K. Speeding up the pace of new product development. J Prod Innov Manag 1999; 16:231-47 [May].

Laursen Keld, Salter Ammon. Open for innovation: The role of openness in explaining innovation performance among UK manufacturing firms. Strateg Manage J 2006; 27:131-50.

Lukas Bryan A, Menon Ajay. New product quality: Intended and unintended consequences of new product development speed. J Bus Res 2004; 57(11): 1258-64.

Lukas Bryan A, Menon Ajay, Bell Simon J. Organizing for new product development speed and the implications for organizational stress. Ind Mark Manage 2002; 31:349-55 [July],

Lyon Douglas W, Ferrier Walter J. Enhancing performance with product-market innovation: The influence of the top management team. J Manag Issue 2002; 14(4):452-69.

Manu Franklyn A, Shram Ven. Innovation marketing strategy environment and performance. J Bus Res 1996; 35:79-91 [January],

Mariampolski Hy. Qualitative Market Research: A Comprehensive Guide. Thousand Oaks: Sage Publications 2001.

Martin Xavier, Salomon R. Knowledge transfer capacity and its implication for the theory of the multinational corporation. J Int Bus Stud 2003; 34:356-73 [July]. 
Miles Robert E, Snow Charles C. Organizational strategy, structure, and process. New York: McGraw-Hill 1978.

Miller Danny, Droge Cornelia, Toulouse Jean-Marie. Strategic process and content as mediators between organizational context and structure. Acad Manage J 1988; 31:544-69 [September].

Morrison Pamela D, Roberts John H, von Hippel Eric. Determinants of user innovation and innovation sharing in a local market. Manage Sci 2000; 46: 1513-27 [December].

Noble Charles H, Sinha Rajiv K, Kumar Ajith. Market orientation and alternative strategic orientations: A longitudinal assessment of performance implications. J Mark 2002; 66:25-39 [October].

Olson Eric M, Slater Stanley F, Hult Tomas G. The performance implications of fit among business strategy, marketing organization structure, and strategic behavior. J Mark 2005; 69:49-65 [July].

Pae Jae H, Kim Namwoon, Han Jin K, Yip Leslie. Managing intraorganizational diffusion of innovations. Ind Mark Manage 2002; 31(8):719-26.

Pombriant Denis. After transactional systems. CRM Mag 2006; 10(3):18.

Schlegelmilch Bodo B, Adamantios Diamantqpoulos, Kreuz Peter. Strategic innovation: The construct its drivers and its strategic outcomes. J Strat Mark 2003; 11:117-32 [June].

Sharma Anurag, Lacey Nelson. Linking product development outcomes to market valuation of the firm: The case of the U. S. pharmaceutical industry. J Prod Innov Manage 2004; 21:297-308 [September].

Siguaw Judy A, Simpson Penny M, Enz Cathy A. Conceptualizing innovation orientation: A framework for study and integration of innovation research. J Prod Innov Manage 2006; 23:556-74.

Subramanian Ashok, Nilakanta Sree. Organizational innovativeness: Exploring the relationship between organizational determinants of innovation, types of innovations, and measures of organizational performance. Omega Int J Manage Sci 1996; 24(6):631 -47.

Tidd Joe. Innovation management in context: Environment, organization and performance. Int J Manag Rev 2001; 3(3):169-83.

Totterdell Peter, Desmond Leach, Kamal Birdi, Chris Clegg, Toby Wall. An investigation of the contents and consequences of major organizational innovations. Int J Innov Manag 2002; 6:343-68 [December].

Tushman Michael L, O’Reilly III Charles A. Ambidextrous organizations: Managing evolutionary and revolutionary change. Calif Manage Rev 1996; 38: 8-30 [Summer]. 
Van de Ven Andrew H, Polley Douglas E, Raghu Garud, Sankaran Venkataraman. The innovation journey. New York: Oxford University Press, 1999.

Vàzquez Rodolfo, Santos Maria Leticia, Alvarez Luis Ignacio. Market orientation innovation and competitive strategies in industrial firms. J Strat Mark 2001; 9:69-90 [March].

Zhang Wei, Zhang David Shuo, Luo Xueming. Technological progress, inefficiency, and productivity growth in the US securities industry, 1980- 2000. J Bus Res 2006; 59:589-94.

Zhou Kevin Zheng, Gao Gerald Yong, Yang Zhilin, Zhou Nan. Developing strategic orientation in China: Antecedents and consequences of market and innovation orientations. J Bus Res 2005; 58:1049-58 [August]. 